Tribhuvan University Journal

Vol. 35, No. 1: 149-162, June, 2020

Research Directorate, Tribhuvan University,

Kathmandu, Nepal

DOI: https://doi.org/10.3126/tuj.v35i1.35878

\title{
CHANGING ROLE OF THE UNIVERSITY TEACHERS: AN AGENDA FOR TRANSFORMATIVE EDUCATION
}

\author{
Rajan Binayek Pasa ${ }^{I^{*}}$ and Suman Kharel ${ }^{1}$ \\ Lecturer, Central Department of Rural Development, Kirtipur, TU. \\ Corresponding author: rajan.pasa@cdrd.tu.edu.np
}

\begin{abstract}
This library based paper appraises importance of transformative education in Nepalese context. In doing so, educational outcomes have been theorized based on Vedic educational philosophy, power and pedagogy as well as fourth goal of sustainable development (quality education for all). This paper comes up with conclusion that transformative education has been becoming international agenda for sustainable development. Nepalese policy also has focused on developing and utilizing human capital potentials. However, modern education system has been re/ producing passive teachers and students even in Universities. Teachers are failed to produce critical students having fullest sense of civic virtues and justice that are enviable for maintaining just society. Thus, better to apply intrinsic, extrinsic and functional power and linking teaching with personal and social development while transmitting of knowledge in the process of socializing students and others. Government mechanisms also need to create conducive environment for letting university teachers to participate during policy formulation and implementation processes. Finally, it is better to apply contextual model for transformative education by the University teachers highlighted in this paper.
\end{abstract}

Keywords: education - learning - knowledge - transformative education - teacher - changing role of the teachers.

\section{INTRODUCTION: SETTING AN AGENDA}

Education, learning and knowledge are interrelated to each other (European Science Foundation, 2011 as cited in UNESCO, 2015). Education is way of learning that is deliberate, intentional, and purposeful and organized. Learning is process of acquiring knowledge and the result of that process; how it is used for the holistic development of individual and society. 
There are three ways of learning (i.e. formal, non-formal and informal). Formal and non-formal educational opportunities suppose certain degree of organized systems whereas informal education supposes less organized that may include learning activities that occur in the work place, community and in daily life, on a self-directed, family-directed, or socially-directed bases. Likewise, knowledge is linked to the cultural, social, environmental and institutional contexts that can be applied to the experience. Hence, educational and training programs can be managed through changing plan, policies and program by state government and donor agencies (Jayasuriya, 2010). Because, education and learning in today's changing world needs to go beyond the process of acquiring, validating and using knowledge and address the issues of creation and control of knowledge (UNESCO, 2015).

In this background, education itself can be seen as main driver for development (UNESCO, 2016). Education is an intrinsically worthwhile for fostering autonomy of the individuals and society (Tooley, 2000). Owing to that, the government of Nepal has not only signed in international policy instruments that focused educational/wellbeing right of the individuals but also provisioned education as a fundamental right of the citizens. Nepalese development policies have helped us to realize education as vehicle for all round development of the country. However, education system also has been transmitting ruling class ideology and reproducing social inequalities through economic infrastructures and superstructures. Education system designed by capitalists has been changing the behavior of local intellectuals for brain drain from rural hinterland to global chain of urban centers for meeting the needs of their interest (Burke, 1992). Nepalese educational system is not an exception to such realities as it has failed to transform existing socio-cultural and economic structures. Education system of Nepal is also guided by dominant cultural ideology of upper caste groups. No doubt, the solution for education system needed to build self-perspective as well as to explore foundations of those self-perspectives or what Foucault calls 'discourse' (localized or contextual but true knowledge) (Danaher G. et al., 2000 as cited in Koirala, 2007).

Reflecting upon those ideas, this paper affirmed that transformative education can uplift overall development of the country. This paper thus tried to highlight changing role of the University teachers and students 
(research objective). Transformative education fosters productive and transformative role of education in development process (An agenda for transformative education). It is significant green signal of transforming ranked society into just society. Transformative education contributes to the sustainable development initiatives for onwards sustainability of future society (Markos \& McWhinney, 2003). More so, it has encouraged teachers and students to understand how local stakeholders are working together for sustainable livelihood, experiencing meaning of learning, creating new socio-economic structures and perceiving civic virtues and a sense of justice (UNESCO, 2015). Beyond curricular and pedagogical practices, transformative education stimulates inner will power of the teachers and students and makes them potential human capital.

\section{METHODS AND MATERIALS}

This paper is solely based on library work or review work. The research issues related to transformative education and changing role of the teachers are appraised from the viewpoints of Vedic educational philosophy, power and pedagogy as well as fourth goal of sustainable development (quality education for all), national policy instruments and other empirical findings. Hence, this study is exploratory in nature that has highlighted contextual model for transformative education.

\section{AN APPRAISAL: TEACHERS' ROLE AND ROLE CHANGE}

"Low morale, depressed, feeling unfairly blamed for the ills of society? You must be a teacher" (Times Education Supplement, 1997, p. 1). In educational process, teachers are means, mediator and transmitter of knowledge. Transmission of school knowledge means instruction of uneducated member of society for the development of the individual and larger society. They must play both in/formal role and responsibility during their job of providing equal accessibility of education in classroom. They have to realize that students are human beings they get bored. They need care for attention, they need love and praise, and they have creativity. Teacher must feel that to error is human, not all humans can be same. True teacher must accept all students about motivating and counseling for their emotional/behavioral problems as the new meaning of education is also based on the unbroken interlinked relationship among the motivation, energy, engagement and the life (Fullan, 2007). 
Teacher has to play their role for improving their educational system for socializing students. In this process, teachers can be a role model among students. However, before that, they must be aware about their role in socializing the students and express value through their action in the classroom (Brint, 1998). Socialization is more than instilling values and standards of conduct with involving three dimensions effort to shape behavior, moral values and cultural styles. Social selection is a process of education as a human right and equity consideration. There are three important aspects a teacher needs to be aware of, (i) relation with oneself, (ii) relation with student and (iii) relation with others (What are the qualities of particular students that others appreciate?) while socializing students (Ravi, 2005).

Similarly, in social process, social role consists of rights and duties or of expected behavior of the teachers. It is a comprehensive pattern of behavior, attitudes, constituting a strategy for coping with a recurrent set of situations in a group, organization, or society (Turner, 1968 as cited in menzies, 2016). Social role is an integrated form of basic role, structural status role, functional group role and value role like role model, hero, and saint (Turner, 1990). Social role continues to be somehow in/directly linked with social role of teachers during appraisal of education and development phenomena. All of these efforts are only for probably making transformative role of education. A new rationale for social development theorizing has to be one which no longer equates development with economic growth and ensure social justice through transformative education (Jayasuriya, 2010).

This approach revealed that teachers are guardian, role model, change agent and key person of each society in the process of education system (e.g. the transmission of knowledge, socialization and social selection (Brint, 1998). Hence, role change can be defined as a change in the shared conception and execution of typical role performance and role boundaries. Role change must be distinguished from role transition or reallocation, the movement of individuals out of one role and into another and normal variability as each incumbent develops a uniquely individual version of a particular role within generally accepted boundaries implemented in relation to varying alter role behavior and in varying situation (Turner, 1990). Eventually, role change not merely performs difference with 
teaching with mission, personal development, team building and social responsibility (Hazen, Gerald \& Boss man, 2004).

\section{VEDIC PHILOSOPHY ON EDUCATION}

In ancient period, we had traditional as well as informal type of educational system. Whole religion and religious institutions had led educational activities by following- Rigveda (mantra as a part of knowledge), Yajurveda (that knowledge guides for work and worship by rituals), Samveda (devolution of knowledge) and Atharvaveda (making diversity in knowledge). Vidhya had been given high emphasized. "Sa VidhyaYaVimuktaye"-Veda (that is Vidya which liberate us). Hinduism focuses on Vidya, which is widely known as value-based education or holistic approach to education that gives wisdom, art of life and makes us peaceful and joyful (Yogi, 2012). Similarly gender equality, respect towards nature, humanity, unity in diversity, social harmony and right livelihood etc. are remarkable messages of Vedic educational system.

Gurur Brahma Gurur Visnu Gururdevo Maheshwarah!Guru Sakshat Parambrahma Tasmai Shree Gurave Namah!!(Nitya Stotrawali: 13 [a collection of everyday prayers]). The rhyme emphasizes that in Vedic education system, Guru (teacher) had known as Brahma (i.e., creator), Guru is Vishnu (i.e., preserver), Guru is Shiva (i.e., destroyer of evil forces), and Guru is real supreme godhead, to whom everybody must bow. They had taught students in Gurukul i.e. Rishikul, Rajkul, Devkul, Pirtikuletc (Ghimire, 2005). Students (shisya) were taught spiritual, religious, and cultural and value based curriculum through aadarsha/anuvutiparak and Guru-Shisyasambhandha pedagogy. It had made both Guru and Shisya more rationale and responsible with regard to knowledge sharing. That had helped to produced moral, humanitarian, natural, vigorous and spiritual work force (Luitel, 2012).

\section{POWER AND PEDAGOGY}

Prominent educationist Pestalozzi has said that teaching is not telling but training that is why teaching is art and teacher are artists. Hence, teachers must establish link between power and pedagogy. There are three types of power such as intrinsic, extrinsic and functional power. Intrinsic power suggests that teacher must be vigorous, humorous, emotionally 
control, multiple intelligence and self-confidence thus, it is a personal capacity of the teachers. Extrinsic power suggests that teachers must be subject expert, resourcefulness, knowledgeable on learning process, skillful in research and curriculum.Functional power suggests teacher to control class, manage educational activities and institutional plan, and develop teaching strategy and evaluation of the students and record keeping (Macclintock, 1992).

Likewise, teachers also need to implement five major aspects of power. First: power enacted in classroom. It is a power of teacher over students and developers of curriculum over classroom. Thus, curriculum must develop through analysis of socio-economic status, power construction and schooling pattern of each society. Second: culture of power (rules for participating power). This power related with dress up, way of talking, writing, interacting practices of teacher while teaching. Third: culture of power is reflection of the rules of the culture of those who have power. Forth: newly entered person can success for acquiring power easier because every local people are so much interested with outsiders. Fifth: with power are seems to be a least aware and least willing to acknowledge its existence (Alexander, 2001).

Pedagogy is a method/strategy of teaching, learning and controlling process in education. These methods and strategies are dependent upon various type of philosophical foundation of education such as idealism, naturalism, realism, existentialism, pragmatism. This entire ism has different philosophy, concept, principle, strategy for preparing pedagogical practices. But common things upon these vary philosophies are in corporation of system policies, histories, school, schooling, classroom, pedagogy and didactics, pedagogy and curriculum pedagogy and culture (Burner, 1996). In teaching, learning and controlling processes of education, pedagogy and curriculum and pedagogy and culture both factors are prominent.

Beyond doubt, teacher must realize why power and pedagogy comes together in educational process. In traditional schooling, power and pedagogy used as a force in the production of docile bodies and used education as a transmission center for cultural reproduction of dominant ruling class. They have neglected to use power and pedagogy simultaneously by that reason they could not success to inadequate treatment of the relationship between power (classroom control) and pedagogy. Class room control both conceptually, practically, teachers thinking and discourse is partitioned 
so that teaching and class room control issue kept distinct by discipline. Because discipline is a technology of power it increases the focus of the body (in economic term of utility) and diminishes of these same force (in political term of obedience) (Foucault, 1982 as cited in Peter, 2004). In practice, power and pedagogy has been considering globally. Developed countries are performing transformative education through functionalize power and pedagogy properly. However, in least/developing countries teachers are not yet properly using power and pedagogy in the process of teaching and learning.

\section{INTER/NATIONAL POLICY INSTRUMENTS}

Sustainable Development Goal (SDG) 4: Ensure inclusive and quality education for all and promote lifelong learning: For proper implementation of SDG: 4,over 1,600 participants from 160 countries adopted the Incheon Declaration for Education 2030, which sets out a new vision for education for the next fifteen years. Equity and inclusion, gender equality, quality and lifelong learning are major components for this framework that tried to ensure that all individuals acquire a solid foundation of knowledge, develop creative and critical thinking and collaborative skills, and build curiosity, courage and resilience (UNESCO, 2016). Developed targets of SDG: 4 also have been enlisted below:

- Target 4.1: By 2030, ensure that all girls and boys complete free, equitable and quality primary and secondary education leading to relevant and effective learning outcomes.

- Target 4.2: By 2030, ensure that all girls and boys have access to quality early childhood development, care and pre-primary education.

- Target 4.3: By 2030, ensure equal access for all women and men to affordable and quality technical, vocational and tertiary education, including university.

- Target 4.4: By 2030, substantially increase the number of youth and adults who have relevant skills, including technical and vocational skills, for employment, decent work and entrepreneurship.

- Target 4.5: By 2030, eliminate gender disparities in education and ensure equal access to all levels of education and vocational training for the vulnerable, including persons with disabilities, indigenous peoples and children in vulnerable situations. 
- Target 4.6: By 2030, ensure that all youth and a substantial proportion of adults, both men and women, achieve literacy and numeracy.

- Target 4.7: By 2030, ensure that all learners acquire knowledge and skills needed to promote sustainable development, including, among others, through education for sustainable development and sustainable lifestyles, human rights, gender equality, promotion of a culture of peace and non-violence, global citizenship and appreciation of cultural diversity and of culture's contribution to sustainable development.

Nepal Country Paper: Federal government of Nepal also has developed below road maps to achieve the targets under SDG: 4 ensuring, by 2030 :

- All girls and boys complete free, equitable and quality primary and secondary education leading to relevant and effective learning outcomes,

- All girls and boys have access to quality early childhood development, care and pre-primary education so that they are ready for primary education,

- Equal access for all women and men to affordable and quality technical, vocational and tertiary education, including university,

- A larger percent the number of youth and adults who have relevant skills, including technical and vocational skills, for employment, decent jobs and entrepreneurship, and

- Elimination of gender disparities in education and ensure equal access to all levels of education and vocational training for the vulnerable, among others.

The proposed specific targets for SDG 4 include 99.5 percent net enrolment and completion of primary education, and 99 percent gross enrollment in secondary education by 2030. The other targets are to ensure that 95 percent of students enrolled in grade one reach grade eight; the proportion of youth and adults who have relevant skills (including technical and vocational skills for employment, decent jobs and entrepreneurship) reaches 75 percent; all youth and at least 98 percent of adults both men and women, achieve literacy and numeracy; gender disparities in tertiary education are eliminated (NPC, 2017). 


\section{CRITICAL REFLECTIONS}

From view point of transformative education, obtaining a quality education is the foundation to improving people's lives and sustainable development. Enrolment in primary education in developing countries has reached 91 percent but 57 million children remain out of school. More than half of children that have not enrolled in school live in Sub-Saharan Africa. An estimated 50 percent of out-of-school children of primary school age live in conflict-affected areas. 103 million youth worldwide lack basic literacy skills, and more than 60 percent of them are women (UN, 2016). However, in practice, more than 1.15 million global children are out of school education (UNESCO, 2010). More than 6 percent Nepalese children have no access to primary education and more than 22 percent children have no access to basic education (DoE, 2012). However, Nepal is committed to enhancing access to education, particularly for the poor and disadvantaged groups. As a result, NER in primary education has reached 96.6 percent in 2015. Similarly, numeracy rate for all of 15 years and above reached 62.2 percent and literacy rate of population of age 15-24 years reached to 88.6 percent in 2015. The gender disparity exists at tertiary levels of education ( 88 men to 100 women). The adult female literacy rate for the population aged 15 and older has also increased drastically (NPC, 2017).

From the view point of development, government of Nepal recently came up with fifteenth plan (NPC, 2019). This plan came up with the long term vision"Prosperous Nepal, Happy Nepali". For that purpose this plan also developed some indicators related to prosperity and happiness (Table 1).

Table 1: Indicators for prosperity and happiness

\begin{tabular}{|c|c|}
\hline 1: Prosperity & 2: Happiness \\
\hline $\begin{array}{l}\text { 1.1 Accessible modern infrastructure } \\
\text { and intensive connectivity }\end{array}$ & 2.1 Well-being and decent life \\
\hline $\begin{array}{l}\text { 1.2 Development and full utilization } \\
\text { of human capital potentials }\end{array}$ & 2.2 Safe, civilized and just society \\
\hline $\begin{array}{l}\text { 1.3 High and sustainable production } \\
\text { and productivity }\end{array}$ & 2.3 Healthy and balanced environment \\
\hline $\begin{array}{l}\text { 1.4 High and equitable national } \\
\text { income }\end{array}$ & $\begin{array}{l}\text { 2.4 Good governance } \\
\text { 2.5 Comprehensive democracy } \\
\text { 2.6 National unity, security and dignity }\end{array}$ \\
\hline
\end{tabular}

Source: Long Term Vision, 2100 
Developmental indicators inserted in above table 1 highlighted long term development vision of the government. The transformative role of education on development issue has been seen directly in second indicators of prosperity, development and full utilization of human capital potentials. However, all the indicators of prosperity and happiness cannot be achieved without transformative and productive role of the teachers highlighted in this paper (Figure 1). From the view point of teachers' role, in Nepal there are total 325519 teachers (120056 female and 205463 male) involving in 35601 schools (23035 community and 6566 institutional), 283 technical stream (9-12) schools, 724 TSLC level and 496 Diploma level technical schools, 1407 campuses, 4 medical institutes and 11 universities (MEST, 2017). This figure covers the teachers who are working in the approved positions, Rahat teachers, teachers hired by the community in community schools and teachers working in institutional schools.

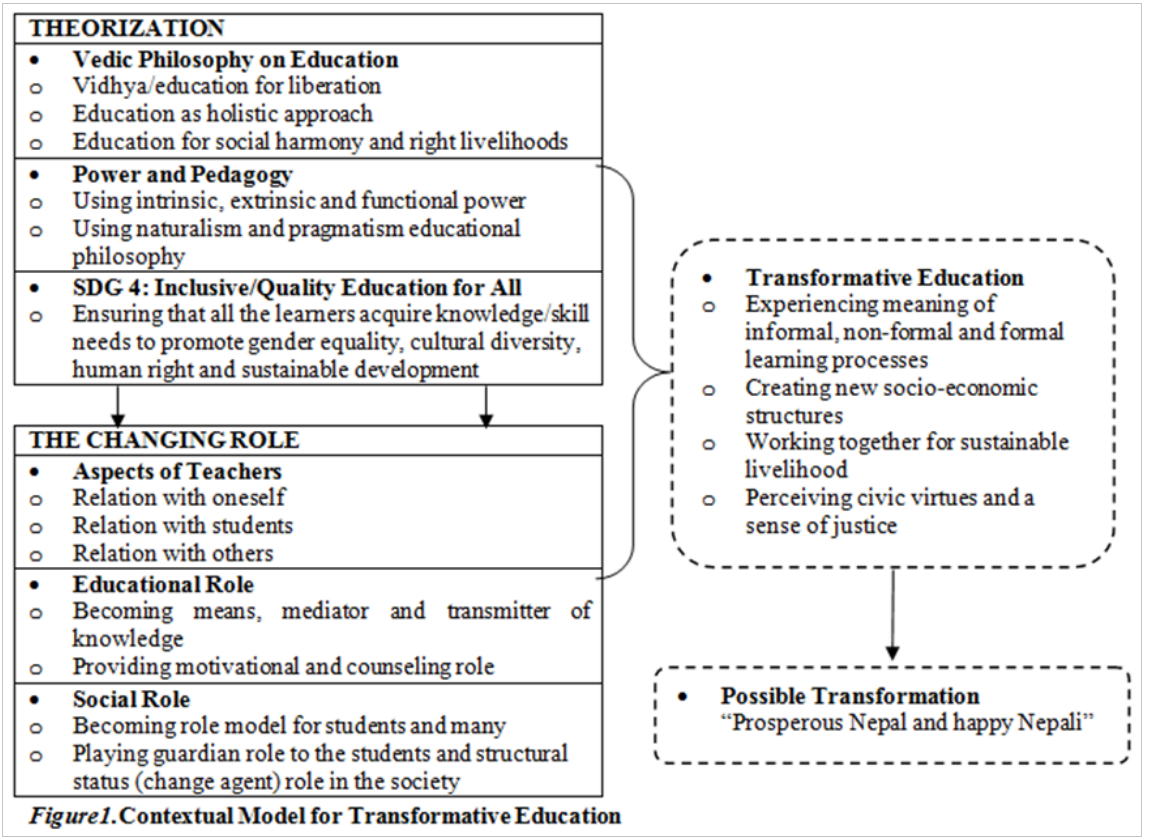

Similarly, total 610622 teachers already got teaching license in which 199732, 307313 and 103577 teachers are belong to primary lower secondary and secondary levels respectively (DoE, 2016). Similarly, even in Tribhuvan University only there are 7966 teaching faculty staffs 
involving in 5 technical institutes (i.e., health, science and technology, engineering, forestry and agriculture and animal science) and 4 general faculties (i.e., humanities and social sciences, education, management and law). Hence, it is a time to perform transformative role of education by the teachers and students. For that purpose changing role of the teachers can play transformative role.

However, in practice, unfortunately, educators, educational researchers, and educational policy makers frequently employ school education system without explaining its social, cultural, economic, and political significance (Sturman, 1997). However, federal government has made provisions for three different mechanisms (federation, provinces and local levels) to formulate/implement educational policies. In this changing context, teachers and local development stakeholders belong to those changing mechanisms must appraise their own Socio-cultural, economic and political structures collectively for implementing transformative role of education in general and for motivating teachers to perform changing role in particular. Teachers also need to restructure colonized reality by taking the risk of bringing such reality into classrooms so that it can be interrogated and transformed into new paradigms of ethical, social and political revolt (Mclaren, 1989, p. 282).

\section{CONCLUSIONS AND IMPLICATIONS}

This paper came up with the conclusion that quality education has become inter/national agenda for sustainable development. Nepalese educational/developmental policies are also focused on quality education and utilization of human capital potentials. In practice, socio-economic and cultural harmony was existed in Nepalese society due to value based education system in the past but modern education system guided by profit motive interest failing to perform accordingly. Instead of that it has been re/ producing passive teachers and students. Even though modern education system of Nepal is still guided by dominant cultural ideology of upper caste groups have been manipulating individual behavior, attitude, feeling and believing of the teachers and students. Teachers are dominated by cultural power and politics and excluded from the discourses of social and education policy. Teachers themselves can improve teaching and learning environment while socializing students for willing civic virtues and a sense of justice. 
They can motivate and encourage students while transmitting of knowledge, socialization and social selection. In this process teacher can apply their intrinsic, extrinsic and functional power and linking teaching with mission, personal development, team building and social responsibility. In order to challenge such structured system, teachers must realize their changing role (i.e., performing educational and social role simultaneously) themselves. In doing so, teachers can establish empowering relationship with self (e.g., individual, self and teachers) and others (e.g., under privileged students, adults and marginalized people) before entering into socialization process. That is impossible without changing inter/national education and development policy instruments by thoughtful participation of the teachers themselves during policy formulation and implementation process. Finally, changing role of the teachers highlighted in this paper (Figure 1) can be performed by University teachers for supporting long term development vision of the country "prosperous Nepal and happy Nepali".

\section{REFERENCES}

Alexander, R. (2001). Culture and pedagogy. International comparison on primary education. USA: Blackwell publisher.

Ball, S. J. (2004). The forms of capital: Pierre Bourdieu Reader in sociology of education. Rutledge Flamer.

Brint, S. (1998). Schools and societies. London: Sage Publication.

Burke, P. (1992). Critical thought series 2: Critical essays on michel foucault. Cambridge: The University Press.

Burner, J. S. (1996). The culture of education. Cambridge MA: Harvard University Press.

DoE (2011). Flash report 2012. Bhaktapur: Department of Education.

DoE (2016). Flash report I (2017-2018). Bhaktapur: Department of Education.

Fullan, M. (2007). The new meaning of educational change (4th ed.). New York:

Ghimire, U. K. (2005). Veedaka vaneeharu. Kathmandu: Author.

Hazen, M. A. Gerald, F. C. \& Boss man, L. (2004). Teaching with mission: Personal development, team building, and social responsibility. Journal of Business Ethic, 51(4): 373-386. 
Jayasuriya, L. (2010). Talking social development seriously. New Delhi: Sage Publication.

Luitel, B. C. (2012). Vedic philosophy. Seminar presentation in KU, 18 August.

Markos, L. \& McWhinney, W. (2003). Editors' perspectives: Auspice. Journal of Transformative Education, 1(1), 3-15.

Mcclintock, R. (1992). The study place exploration in education. Cumulative curriculum project publication. Office for Standard Education Report.

Mclaren, P. (1989). Life in schools: An introduction to critical pedagogy in the foundation of education (2nd ed.). New York: Longman Publishing.

Menzies, K. (2016). Sociological theory in use. London: Routledge Library Edition.

MEST (2017). Education in figures 2017, A glance report. Kathmandu: Ministry of Education, Science and Technology, Policy and Research Section.

NPC (2017).Sustainable development goals: Status and road map (201630). National Planning Commission. Unofficial Translation an Approach Paper to the Fifteenth Plan (2019 - 2021). Kathmandu: Government of Nepal.

Peter, M. A. (2004). Educational research; game of truth and ethics of subjectivity. Journal of Educational Enquiry, 5 (2), 50-63.

Sturman, A. (1997). Social justice in education. Melbourne: Australian council for Educational research.

Tooley, J. (2000). Reclaiming education. London: Wellington House Cassell.

Turner, R. H. (1990). Role change. Annual review of sociology, 16: 87-110. Teachers College Press.

UNESCO (2016). Incheon declaration and framework for action for the implementation of sustainable development goal 4. Korea:United Nations Education, Science and Cultural Organization.

UNESCO (2010). Statistical year book. Paris: United Nations Education, Science and Cultural Organization. 
162 CHANGING ROLE OF THE UNIVERSITY TEACHERS': AN AGENDA ...

UNESCO (2015). Towards a global common good? Rethinking education. Paris: Publication of United Nations Education, Science and Cultural Organization.

Yogi, C. M. (2012). Global message through oriental Hinduism philosophy. One day seminar presentation in Kathmandu University. July16, 2012. 